\title{
Reproductive aspects of the semi-aquatic snake Erythrolamprus miliaris (Dipsadidae: Xenodontini) in the state of Rio de Janeiro, southeastern Brazil
}

\author{
ALEXIA EISFELD ${ }^{1}$ and DAVOR VRCIBRADIC ${ }^{2}$ \\ ${ }^{1}$ Programa de Pós-Graduação em Ciências Biológicas, Universidade Federal do Estado do Rio \\ de Janeiro, Avenida Pasteur, 458, Urca, 22290-255 Rio de Janeiro, RJ, Brazil \\ ${ }^{2}$ Departamento de Zoologia, Instituto de Biociências, Universidade Federal do Estado do Rio \\ de Janeiro, Avenida Pasteur, 458, Urca, 22290-255 Rio de Janeiro, RJ, Brazil \\ Manuscript received on August 28, 2017; accepted for publication on June 29, 2018
}

\begin{abstract}
How to cite: EISFELD A AND VRCIBRADIC D. 2019. Reproductive aspects of the semi-aquatic snake Erythrolamprus miliaris (Dipsadidae: Xenodontini) in the state of Rio de Janeiro, southeastern Brazil. An Acad Bras Cienc 91: e20170657. DOI 10.1590/0001-3765201920170657.
\end{abstract}

\begin{abstract}
We analyzed some aspects of reproduction and sexual dimorphism of the semi-aquatic dipsadid snake Erythrolamprus miliaris in the state of Rio de Janeiro, southeastern Brazil. We detected sexual dimorphism in body size (snout-vent length), with females averaging larger than males, but no sexual dimorphism in the relative length of the tail. Oviductal eggs and secondary follicles were found in all seasons, suggesting that female reproductive cycles are continuous, in spite of the tropical seasonal climate in the region. Reproductive males were present throughout the year, suggesting a continuous cycle for males as well. Clutch size averaged $10.3 \pm 4.8$ (range 4-21) and there was a positive and significant relationship between clutch size and female size. Compared to conspecific populations previously studied in other Atlantic Rainforest areas, populations of E. miliaris from the state of Rio de Janeiro appear more similar overall in their reproductive traits to a more northern population from the state of Bahia than to populations from further south in the states of São Paulo and Paraná.
\end{abstract}

Key words: Atlantic Forest, reproduction, sexual dimorphism, Squamata.

\section{INTRODUCTION}

Snakes living in tropical and subtropical regions of the New World may have a wide diversity of reproductive strategies, despite the relatively mild climatic variations of their habitat (compared to temperate regions) (e.g. Pizzatto et al. 2008). Reproductive cycles of those species vary from non-seasonal (i.e. continuous) to strongly seasonal (e.g. Marques and Puorto 1998, Pinto and

Correspondence to: Alexia Eisfeld

E-mail: alexia_magalhaes@hotmail.com

ORCid: http://orcid.org/0000-0003-3704-2944
Fernandes 2004, López et al. 2009, Orofino et al. 2010, Oliveira et al. 2011). Moreover, some species with extensive distributional ranges may present geographic variation in reproductive traits such as clutch/litter size and timing of reproduction, and even in the degree of sexual dimorphism (e.g. Pizzatto and Marques 2006a, b, Pizzatto et al. 2008, Leite et al. 2009, Siqueira et al. 2013, Quintela et al. 2017).

Erytrolamprus miliaris (Linnaeus, 1758) (Dipsadidae, Xenodontinae) is a semi-aquatic oviparous snake widely distributed in South America east of the Andes (Gans 1964, Dixon 1989). It is a 
polytypic species, with five subspecies currently recognized (Uetz et al. 2016). In spite of being often locally abundant and commonly found in urban and peri-urban areas, particularly in southeastern Brazil (e.g. Hartmann et al. 2009, Pontes et al. 2009, Barbo et al. 2011), information available on the ecology of E. miliaris still consists mostly of isolated reports regarding diet and behavior (e.g. Lema et al. 1983, Michaud and Dixon 1989, Marques and Souza 1993, Machado et al. 1998, Marques and Sazima 2004, Hartmann et al. 2009, Vrcibradic et al. 2012, Duarte et al. 2014, Muscat et al. 2016, Muscat and Moroti 2018). Regarding aspects of reproduction there is more information available (Pizzatto and Marques 2006a, b, Pizzatto et al. 2008, Rojas et al. 2019), though studies are still scarce if we consider the species' wide geographic range. Pizzatto and Marques (2006a, b) presented comprehensive information on reproductive aspects of four Brazilian Atlantic Forest populations of Erythrolamprus miliaris, being two in coastal areas (a northern one in the state of Bahia and a southern one in the states of São Paulo and Paraná) and two from inland areas (a more northern one in the state of São Paulo and a southern one in the state of Paraná). They found no significant differences among the four populations regarding some traits (e.g. clutch size), but noted certain differences in the population of southern Bahia (the northernmost population they studied) compared with the other three, including a continuous (i.e. non-seasonal) female reproductive cycle. Pizzatto and Marques (2006a) also recorded that, in all four populations, females tend to attain larger body sizes than males, whereas the dimensions of the head do not differ between sexes. They did not test whether the sexes differ in this species regarding the relative length of the tail (a common trait found among snakes in general, with males usually showing higher values; King 1989). Nevertheless, Giraudo et al. (2006) reported a tendency for relatively longer tails in males compared to females in the subspecies $E$. miliaris orinus.

In the present study we analysed aspects of the reproductive biology and sexual dimorphism of Erythrolamprus miliaris from the state of Rio de Janeiro, in southeastern Brazil, making comparisons with the other populations previously studied by Pizzatto and Marques (2006a, b).

\section{MATERIALS AND METHODS}

Recent phylogenetic studies based on molecular data uncovered polyphyly and paraphyly in the genus Liophis (Zaher et al. 2009, Vidal et al. 2010, Grazziotin et al. 2012). Some taxonomic actions have been proposed to circumvent the situation, including the synonimization of Liophis and Umbrivaga with Erythrolamprus, which represents the oldest available name for the largest clade of former Liophis (Grazziotin et al. 2012). Some authors prefer to take a more conservative attitude, recognizing Liophis, Erythrolamprus and Umbrivaga as valid genera until more comprehensive phylogenetic analyses of that clade are available (Curcio et al. 2009, Myers and McDowell 2014, Wallach et al. 2014). We herein follow Uetz et al. (2016) and use the name Erythrolamprus, while acknowledging that further studies on the phylogenetic relationships of this group of snakes are needed to stabilize its nomenclature.

Located at $20^{\circ} 30^{\prime}-23^{\circ} 30^{\prime} \mathrm{S}$ and $41^{\circ}-45^{\circ} \mathrm{W}$, the state of Rio de Janeiro is totally inserted within the Atlantic Forest domain, one of the world's biodiversity "hotspots" (Mittermeier et al. 2004). The state presents climatic seasonality throughout most of its extension, with wet and warm conditions during spring and summer and some decrease in rainfall and mean daily temperatures during autumn and winter (CLINO 1996). We examined specimens of E. miliaris from the state of Rio de Janeiro deposited in the reptile collections of 
Museu Nacional (MNRJ, $\mathrm{n}=170$ ), Universidade do Estado do Rio de Janeiro (CH-UERJ, $\mathrm{n}=18$ ), Universidade Federal do Rio de Janeiro (ZUFRJ, $\mathrm{n}=$ 15), Universidade Federal Rural do Rio de Janeiro (RU, $\mathrm{n}=13$ ) and Instituto Vital Brasil (IVB, $\mathrm{n}=$ 5), all located in the state (see Appendix). The year of collection of those snakes ranged from 1941 to 2016, though most (67\%) were collected after 2000. The specimens came mostly from coastal lowlands and foothills of the Serra do Mar mountains. The state of Rio de Janeiro is located between the two coastal regions (in Bahia and São Paulo/Paraná) whose populations of $L$. miliaris were studied by Pizzatto and Marques (2006a, b) (Figure 1).

Snout-vent length (SVL) and tail length (TL) were taken with a measuring tape (to the nearest $1 \mathrm{~mm}$ ). Then, each specimen was dissected for sexing and examination of its gonads. For females, all eggs and mature ovarian follicles (in secondary vitellogenesis), when present, were counted and measured in their length, width and depth (to the nearest $0.1 \mathrm{~mm}$ ). Volume of eggs and follicles was estimated by the formula: $\mathrm{V}=4 / 3 a b c$ (in which $\mathrm{V}=$ volume, $a=$ length $/ 2, b=$ width $/ 2$ and $c=\operatorname{depth} / 2$; see Pleguezuelos and Feriche 1999). Females were considered reproductive if they contained vitellogenic ovarian follicles $>10 \mathrm{~mm}$ along the greater axis or eggs in the oviducts (according to Pizzatto and Marques 2006a ,b). The minimum size at reproductive maturity for females was based on the SVL of the smallest female in that condition. The minimum size at reproductive maturity for males was based on the SVL of the smallest male with opaque and convoluted ductus deferens (indicative of the presence of sperm; e.g. Shine 1977, Pizzatto and Marques 2006a). Frequency of reproductive females was estimated based on the ratio between the number of reproductive females and the total number of females, (see Pizzatto and Marques 2006b). The same procedure was used to estimate the frequency of reproductive males.

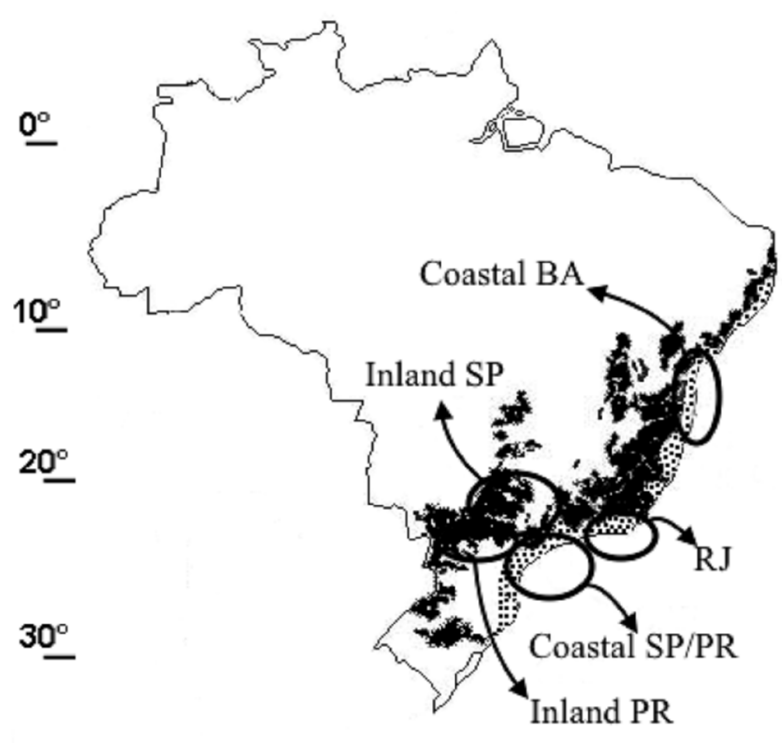

Figure 1 - Map of Brazil showing approximate geographic coverage for our studied sample of Erythrolamprus miliaris from the state of Rio de Janeiro (RJ) and for the samples studied by Pizzatto et al. (2006a, b) from states of Bahia (BA), São Paulo (SP), and Paraná (PR). Modified from Pizzatto et al. (2006a, b).

Since we have no precise information on the size of neonates at the time of hatching in the studied population of L. miliaris, we considered the SVL of the largest field-collected neonate (182 $\mathrm{mm}$ ) recorded by Pizzatto and Marques (2006b) as the maximum size of hatchlings for our population. Therefore, all individuals with SVL equal or smaller than $182 \mathrm{~mm}$ were considered as hatchlings. Occurrence of hatchlings at a given month was considered as an evidence of recruitment occurring at that month. When two or more neonates of similar size had the same date, place of collection, and sequential voucher numbers in the collection they were considered as belonging to the same clutch.

We tested for differences between males and females in SVL (using a t-test) and in TL (using analysis of covariance - ANCOVA, with SVL as a covariate). Following Pizzatto and Marques (2006b) and various other authors/studies (e.g. Alencar and Nascimento 2014, Stender-Oliveira et al. 2016), 
we estimated clutch size based on pooled data from females containing oviductal eggs and females containing follicles in secondary vitellogenesis. Although females with follicles $>10 \mathrm{~mm}$ along the greater axis were considered reproductive, we did not consider follicles under $15 \mathrm{~mm}$ for estimates of clutch size, as the smaller vitellogenic follicles may sometimes be reabsorbed by the snake's organism (L. Pizzatto, pers. comm.). If a female contained oviductal eggs and vitellogenic follicles simultaneously, only the eggs were considered for clutch size estimation. The effect of female size (SVL) on clutch size (based on mature follicles and eggs) was tested by simple linear regression analyses.

Basic statistics given throughout the text are represented by arithmetic means and standard deviations. Before running statistical tests we tested for normality of data distribution using Kolmogorov-Smirnov tests (Zar 1999) and, since the assumptions were met on every occasion, we used only parametric statistics. All statistical analyses were performed using the software SYSTAT 11.

\section{RESULTS}

We examined 221 specimens, comprising 54 males (43 adults and 11 juveniles), 123 females ( 70 adults and 53 juveniles), 42 hatchlings, and two juveniles of indeterminate sex. Adult males and females of $E$. miliaris differed significantly in mean SVL $(\mathrm{t}=8.86$, $\mathrm{p}<0.001$, df $=111$ ), with females (mean SVL $=$ $577.5 \pm 109.5 \mathrm{~mm}$, range $445-921 \mathrm{~mm}, \mathrm{n}=70$ ) being larger than males (mean SVL $=394.2 \pm 102.1$ $\mathrm{mm}$, range $270-705 \mathrm{~mm}, \mathrm{n}=43)$. Mean female SVL at maturity and size of the smallest mature female were smaller than those of E. miliaris populations from São Paulo and Paraná and similar to those from Bahia, but both mean and minimum SVL of mature males were smaller than those of all other conspecific populations (Table I). Mean tail length was $137.6 \pm 22.2 \mathrm{~mm}$ (range $99-223$ $\mathrm{mm}, \mathrm{n}=63$ ) in adult females and $97.2 \pm 23.8 \mathrm{~mm}$ (range $65-157 \mathrm{~mm}, \mathrm{n}=39$ ) in adult males. There was no significant difference in the relative length of the tail between sexes (ANCOVA: $\mathrm{F}_{1,1,99}=1.14$, $\mathrm{p}=0.289)$.

Considering the 43 sexually mature males, $36(83.7 \%)$ had convoluted and opaque ducti

TABLE I

Mean and minimum SVL (in mm) of sexually mature males and females, percentage of reproductive females in the sample, and clutch size and its relationship to female SVL in Erythrolamprus miliaris from Rio de Janeiro State (data from present study, in bold) and from populations from other Brazilian states (data from Pizzatto and Marques 2006b).

\begin{tabular}{|c|c|c|c|c|c|}
\hline & \multirow[t]{2}{*}{ Bahia } & \multicolumn{3}{|c|}{ São Paulo and Paraná } & \multirow[t]{2}{*}{ Rio de Janeiro } \\
\hline & & coastal SP/PR & Inland SP & Inland PR & \\
\hline Mean 우우 SVL & 555.8 & 713.3 & 676.2 & 670.9 & 577.5 \\
\hline Min. mature $q \rho$ SVL & 400 & 534 & 505 & 507 & 445 \\
\hline Mean $\widehat{\partial} \widehat{\partial} \mathrm{SVL}$ & 465.4 & 580.6 & 539.1 & 532.3 & 394.2 \\
\hline Min. mature $\widehat{\partial} \widehat{S V L}$ & 355 & 410 & 417 & 380 & 270 \\
\hline$\%$ reproductive $ㅇ$ & 32.8 & 52.5 & 58.3 & 53.6 & 31.9 \\
\hline Clutch size & $9.0 \pm 3.4$ & $10.2 \pm 2.8$ & $10.9 \pm 6.5$ & $10.0 \pm 4.4$ & $10.3 \pm 4.9$ \\
\hline \multirow{2}{*}{ Clutch size $\mathrm{x}$ SVL } & $\mathrm{r}^{2}=0.50$ & $\mathrm{r}^{2}=0.38$ & $r^{2}=0.92$ & $\mathrm{r}^{2}=0.38$ & $r^{2}=0.34$ \\
\hline & $\mathrm{p}<0.001$ & $\mathrm{p}<0.01$ & $\mathrm{p}<0.001$ & $\mathrm{p}<0.01$ & $\mathrm{p}<0.01$ \\
\hline
\end{tabular}


deferens, and these were recorded in all months of the year. Of the 70 mature females examined, only $22(31.9 \%)$ were reproductive (Table I). Females with oviductal eggs occurred in February, July, September and November and females with mature follicles occurred in January, June, August, October and December (Figure 2), suggesting that the reproductive cycle is extended. Only one female (MNRJ 10975; SVL = $627 \mathrm{~mm}$ ), collected in November 2003, contained oviductal eggs (nine) and mature follicles (eight) simultaneously (only the former were considered for the clutch size estimate in this case). Mean clutch size was 10.3 \pm 4.8 (range $4-21, \mathrm{n}=18$ ) and was positively and significantly influenced by female SVL $\left(\mathrm{r}^{2}=0.335\right.$, $\mathrm{p}<0.05$ ) (Table I, Figure 3). Mean egg volume was $1622.2 \pm 1071.2 \mathrm{~mm}^{3}$ and was similar to those of most other conspecific populations (Table II). Hatchling-sized individuals were recorded in most months, except in August and September (Figure 4), and their mean SVL was $156.9 \pm 12.7 \mathrm{~mm}$ (range 121-182 mm, $\mathrm{n}=42$ ), with the minimum value being closer to that of the Bahia population than to those of the more southern ones (Table II).

\section{DISCUSSION}

Our data indicated that E. miliaris females are generally larger and reach sexual maturity with a greater body size than males, as previously reported by Pizzatto and Marques (2006a) for other populations. This appears to be the common pattern of sexual dimorphism for snakes in general (Shine 1994) and for xenodontines in particular (Pizzatto et al. 2008, López et al. 2009, Panzera and Maneyro 2013). Selective pressures to enhance reproductive output are usually invoked to explain this pattern, as greater body proportions in female snakes provide increased internal space for developing more eggs/ embryos (e.g. Shine 1994). Indeed, clutch size was positively correlated with female body size in the studied population of E. miliaris, as it was in other conspecific populations studied by Pizzatto and Marques (2006b) and in several other species of xenodontines (Pizzatto et al. 2008, Panzera and Maneyro 2013).

Males in our sample had small mean and minimum sizes (SVL) at maturity compared to those of all four conspecific populations studied by Pizzatto and Marques (2006b), including those

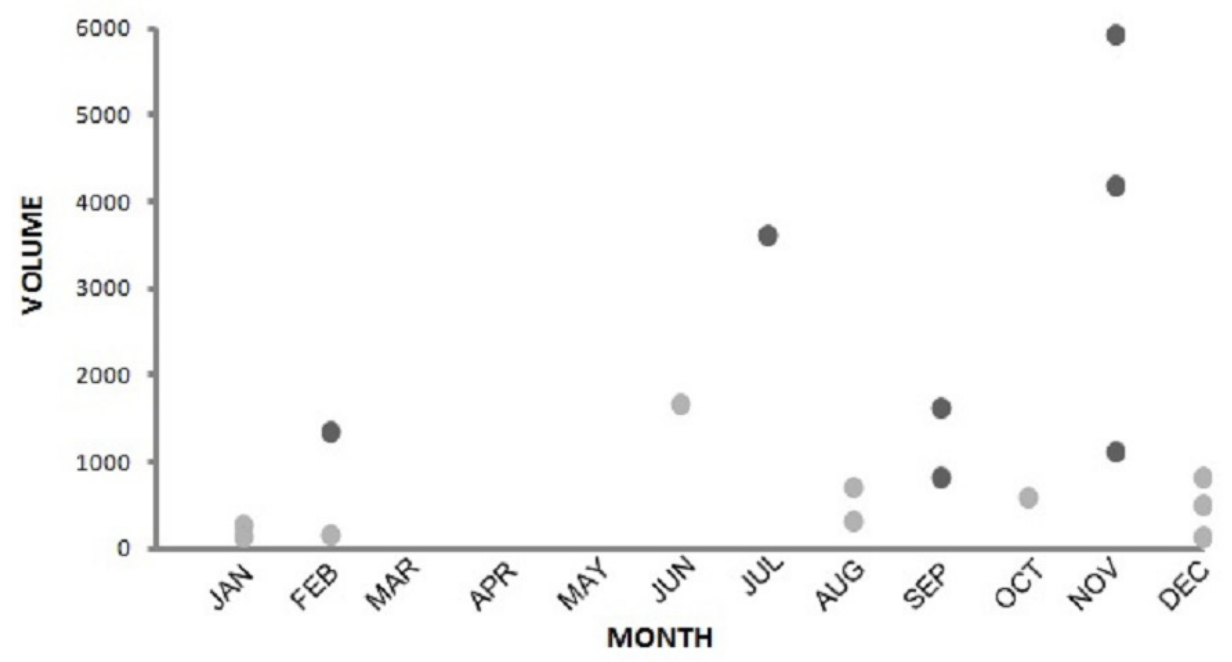

Figure 2 - Size distribution (volume, in $\mathrm{mm}^{3}$ ) of mature follicles (light gray dots) and oviductal eggs (dark gray dots) of Erythrolamprus miliaris from the state of Rio de Janeiro throughout the year. 
TABLE II

Average egg volume (in $\mathrm{mm}^{3}$, with range and sample sizes in parentheses) and size (SVL) of the smallest fieldcollected hatchling (in mm) of Erythrolamprus miliaris from Rio de Janeiro State (in bold) compared to other populations studied by Pizzatto and Marques (2006b).

\begin{tabular}{|c|c|c|}
\hline Population & $\begin{array}{l}\text { Mean egg volume } \\
\left(\mathrm{mm}^{3}\right)\end{array}$ & $\begin{array}{c}\text { Minimum } \\
\text { hatchling } \\
\text { SVL }\end{array}$ \\
\hline Coastal Bahia & $\begin{array}{c}1520.0 \pm 557.3 \\
(503.0-2693.3, \mathrm{n}=53 \\
\quad \text { eggs, } 5 \text { clutches })\end{array}$ & 113 \\
\hline $\begin{array}{l}\text { Coastal São } \\
\text { Paulo/Paraná }\end{array}$ & $\begin{array}{c}1782.2 \pm 701.9 \\
(1051.7-3805.0, \mathrm{n}=41 \\
\text { eggs, } 5 \text { clutches })\end{array}$ & 169 \\
\hline Inland São Paulo & $\begin{array}{c}1812.5 \pm 532 ., 9 \\
(971.2-3263.5, \mathrm{n}=63 \\
\text { eggs, } 4 \text { clutches })\end{array}$ & 170 \\
\hline Inland Paraná & $\begin{array}{c}2926.3 \pm 1090.9 \\
(1682.0-2828.2, \mathrm{n}=51 \\
\text { eggs, } 7 \text { clutches })\end{array}$ & 150 \\
\hline Rio de Janeiro & $\begin{array}{c}1622.2 \pm 1071.2 \\
(88.4-5932.2, \mathrm{n}=92 \\
\text { eggs, } 9 \text { clutches })\end{array}$ & 121 \\
\hline
\end{tabular}

from Bahia (the smallest-sized population studied by those authors). We found this surprising, since females in our sample were comparable in the same measurements to those from Bahia. Actually, onethird of the 36 males showing signs of reproductive activity (based on the observation of the ducti deferens) measured 270-345 $\mathrm{mm}$ in SVL, whereas the smallest reproductive male from Bahia had an SVL of $355 \mathrm{~mm}$ (Pizzatto and Marques 2006b). This suggests that males in the studied population are reproductively active at relatively small sizes. This is also reinforced by the fact that the largest male in our sample (705 mm SVL) was similar in size to the largest males of the population from Bahia $(650 \mathrm{~mm})$ and of two of the southern populations (ca. $750 \mathrm{~mm}$ ) studied by Pizzatto and Marques (2006b), indicating that males from Rio de Janeiro may grow as large as those from other populations. More detailed studies, including histological examination of gonads and analyses of populations from areas between southern Bahia

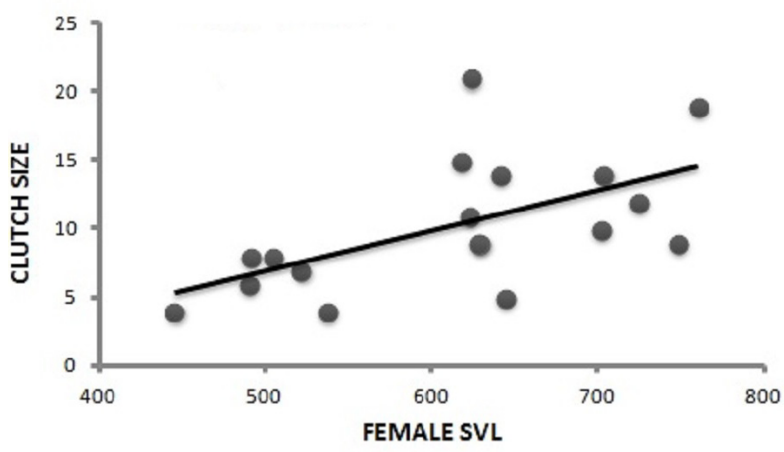

Figure 3 - Linear regression between clutch size and SVL of females (in mm) of Erythrolamprus miliaris from the state of Rio de Janeiro.

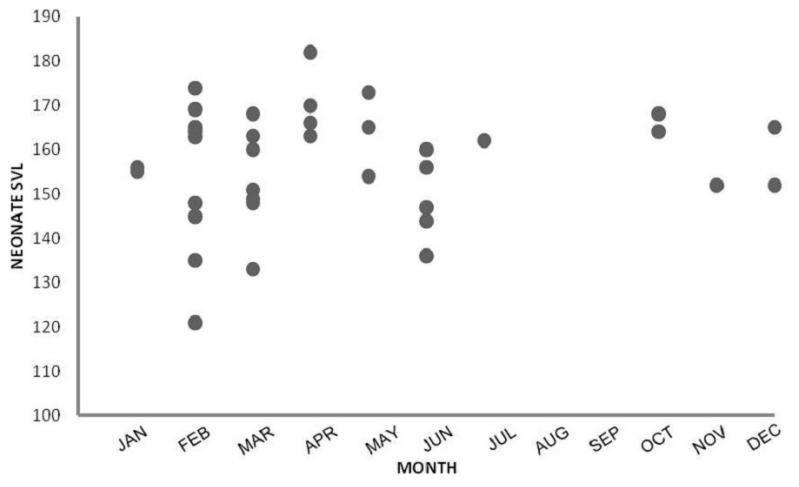

Figure 4 - Size distribution (SVL, in $\mathrm{mm}$ ) of neonates of Erythrolamprus miliaris from the state of Rio de Janeiro throughout the year; mean values were used in cases when there were two or more neonates from a single clutch.

and Rio de Janeiro, may elucidate if there really is a trend for males of the latter population to mature at smaller sizes than in other regions.

The lack of sexual dimorphism in relative tail length in the studied population of E. miliaris was somewhat unexpected. Male snakes tend to have proportionally longer tails than females (King 1989), and this has been reported for E. miliaris orinus (Giraudo et al. 2006), as well as for other species of Erythrolamprus (Giraudo et al. 2006, López et al. 2009, Quintela et al. 2017). However, Alencar and Nascimento (2014) did not find intersexual differences in relative tail length for $E$. $p$. poecilogyrus, a result similar to that of the present study. On the other hand, Prieto et al. (2012) 
reported proportionally longer tails in females compared to males (i.e. the reverse of the usual trend) in a population of E. p. sublineatus (though they apparently included immature individuals in their samples, which limits the comparisons with our results). Thus, at the moment it is not clear if there is a pattern of sexual dimorphism in tail length in E. miliaris and other closely related species, and data on more populations and taxa are needed.

Our data suggest continuous reproductive cycles for both male and female E. miliaris in Rio de Janeiro (although we did not carry out histological analyses to confirm reproductive activity in males). Pizzatto and Marques (2006a) also reported continuous reproductive cycles in $E$. miliaris from the northern coastal Atlantic Forest (state of Bahia), but not in populations from southeastern and southern Atlantic Forest (states of São Paulo and Paraná), whose vitellogenesis and egg-laying were restricted to the spring-summer period. The state of Rio de Janeiro is located south of Bahia and north of São Paulo, but unlike southern Bahia (whose climate has little or no seasonality) it presents seasonal variation in temperature and rainfall (though generally less pronounced than in São Paulo). Nevertheless, the reproductive cycle of E. miliaris in Rio de Janeiro does not seem to be much influenced by seasonality, differently from what occurs in more southern portions of this snake's range. Snakes of the Tribe Xenodontini and some other dipsadids in South America frequently have continuous or broad female reproductive cycles, even when living in areas with seasonal climates (Pizzatto et al. 2008). Males apparently remain reproductive throughout the year in most species of Xenodontini (Pizzatto et al. 2008, Sivan et al. 2016) as observed for E. miliaris in the present study.

The percentage of breeding females (reproductive frequency) of E. miliaris in our sample was low compared with conspecific populations in São Paulo and Paraná, and similar to that of populations occurring in southern Bahia (see Pizzato and Marques 2006b). As the females from southern populations tend to be more active during the warmer and wetter months of the year (which correspond to the breeding season), they may be collected with higher frequencies during that period (Pizzatto and Marques 2006a), which would explain the high percentages of reproductive females in the samples (Pizzatto and Marques 2006b). In populations with extended or continuous reproduction (such as those of Bahia and Rio de Janeiro), on the other hand, such bias would be less marked. The occurrence of one female containing both oviductal eggs and vitellogenic follicles indicate that females in Rio de Janeiro may eventually produce more than one clutch per year, as also observed in the conspecific populations from São Paulo and Paraná (Pizzatto and Marques 2006a) and in other species of Xenodontini (Pinto and Fernandes 2004, Panzera and Maneyro 2013, Quintela et al. 2017).

Mean clutch size (based both on the numbers of eggs and of mature follicles) of the studied population of E. miliaris was similar to those of conspecific populations from other regions of Brazil (which did not differ statistically from each other; Pizzatto and Marques 2006b). Although we could not compare our data statistically with those of Pizzatto and Marques (2006b), the similarity in mean values and ranges between the two studies suggest that clutch size in this species does not show notable geographic variation, at least within the Atlantic Forest domain. Erythrolamprus miliaris is among the largest species of Xenodontini, and also produces large clutches when compared to other species of the tribe (Pizzatto et al. 2008). Egg size also does not seem to present much geographic variation in E. miliaris, though hatchling size does. As observed in other reproductive parameters, the minimum size (SVL) of hatchlings of E. miliaris from Rio de Janeiro (121 mm) was more similar to that reported for the population from coastal 
Bahia $(113 \mathrm{~mm})$ and relatively small in comparison to those from São Paulo and Paraná (Pizzatto and Marques 2006b).

Erythrolamprus miliaris from Rio de Janeiro were overall more similar in their reproductive traits to conspecifics from Bahia than to populations from further south. This could reflect phylogenetic history, as populations from Rio de Janeiro and Bahia are assigned to the same subspecies, $E$. m. merremi (Dixon 1989), while more southern populations are referred to $E$. $m$. orinus (though the validity of those taxa remain to be properly evaluated). Alternatively (or complementarily), it could reflect the plasticity in reproductive aspects of a widely distributed species. A comprehensive phylogeographic analysis of E. miliaris, particularly along the eastern Brazilian Atlantic Rainforest domain, could be crucial to answer those questions.

\section{ACKNOWLEDGMENTS}

We thank Paulo Passos, Daniel S. Fernandes, Hélio Ricardo da Silva, Aníbal Melgarejo and Oscar Rocha Barbosa for allowing us to examine specimens housed in herpetological collections under their care. We are also thankful to Ligia Pizzatto for preparing the map.

\section{AUTHOR CONTRIBUTIONS}

AE contributed by examining and measuring the snake specimens, doing some of the statistical tests, preparing the figures and writing the text. DV contributed by doing some of the statistical tests and writing the text.

\section{REFERENCES}

ALENCAR LRV AND NASCIMENTO LB. 2014. Natural history data of a common snake suggest inter-populational variation and conservatism in life history traits: the case of Erythrolamprus poecilogyrus. Herpetol J 24: 79-85.

BARBO FE, MARQUES OAV AND SAWAYA RJ. 2011. Diversity, natural history, and distribution of snakes in the municipality of São Paulo. S Am J Herpetol 6: 135-160.
CLINO. 1996. Climatological Normals (CLINO) for the period 1961-1990, Geneva: World Meteorological Organization, $768 \mathrm{p}$.

CURCIO FF, PIACENTINI VQ AND FERNANDES DS. 2009. On the status of the snake genera Erythrolamprus Boie, Liophis Wagler and Lygophis Fitzinger (Serpentes, Xenodontinae). Zootaxa 2173: 66-68.

DIXON JR. 1989. A key and checklist to the neotropical snake genus Liophis, with country list and maps. Smithson Herpetol Inf Serv 79: 1-28.

DUARTE MR, GARRONE NETO D, VASKE JUNIOR T AND PINHEIRO MAA. 2014. Predation on the sleeper goby, Guavina guavina (Perciformes, Eleotridae), by the military ground snake, Erythrolamprus miliaris orinus (Serpentes, Dipsadidae), in a mangrove area of Southeastern Brazil. Herpetol Notes 7: 577-580.

GANS C. 1964. A redescription of, and geographic variation in Liophis miliaris Linné, the common water snake of southeastern South America. Am Mus Novit 2178: 1-58.

GIRAUDO AR, ARZAMENDIA V AND CACCIALI P. 2006. Geographic variation and taxonomic status of the southernmost populations of Liophis miliaris (Linnaeus, 1758) (Serpentes: Colubridae). Herpetol J 16: 213-220.

GRAZZIOTIN FG, ZAHER H, MURPHY RW, SCROCCHI G, BENAVIDES MA, ZHANG Y AND BONATO SL. 2012. Molecular phylogeny of the New World Dipsadidae (Serpentes: Colubroidea): A reappraisal. Cladistics 28: 437-459.

HARTMANN PA, HARTMANN MT AND MARTINS M. 2009. Ecology of a snake assemblage in the Atlantic Forest of southeastern Brazil. Pap Avul Zool (São Paulo) 49: 343-360.

KING RB. 1989. Sexual dimorphism in snake tail length: sexual selection, natural selection, or morphological constraint? Biol J Linn Soc 38: 133-154.

LEITE PT, NUNES SF, KAEFER IL AND CECHIN SZ. 2009. Reproductive biology of the Swamp Racer Mastigodryas bifossatus (Serpentes: Colubridae) in subtropical Brazil. Zoologia 26: 12-18.

LEMA T, ARAÚJO M AND AZEVEDO A. 1983. Contribuição ao conhecimento da alimentação e do modo alimentar de serpentes do Brasil. Comun Mus Cienc PUCRS, Sér Zool 26: 41-121.

LÓPEZ SM, GIRAUDO AR, ARZAMENDIA V AND CHIARAVIGLIO M. 2009. Biología reproductiva de la serpiente semiacuática Liophis semiaureus (Serpentes, Colubridae) en el nordeste de Argentina. Rev Chil Hist Nat 82: 233- 244.

MACHADO RA, BERNARDE PS AND MORATO SAA. 1998. Liophis miliaris. (Common Water Snake). Prey Herpetol Rev 29: 45.

MARQUES OAV AND PUORTO G. 1998. Feeding, reproduction and growth in the crowned snake Tantilla 
melanocephala (Colubridae), from southeastern Brazil. Amphibia-Reptilia 19: 311-318.

MARQUES OAV AND SAZIMA I. 2004. História natural dos répteis da estação ecológica Juréia-Itatins. In: Marques OAV and Duleba W (Eds), Estação Ecológica JuréiaItatins. Ambiente Físico, Flora e Fauna, Ribeirão Preto: Holos, p. 257-277.

MARQUES OAV AND SOUZA VC. 1993. Nota sobre a atividade alimentar de Liophis miliaris no ambiente marinho (Serpentes, Colubridae). Rev Brasil Biol 53: 645- 648.

MICHAUD EJ AND DIXON JA. 1989. Prey items of 20 species of the Neotropical colubrid snake genus Liophis. Herpetol Rev 20: 39-41.

MITTERMEIER RA, GIL PR, HOFFMANN M, PILGRIM J, BROOKS T, MITTERMEIER CG, LAMOREUX J AND FONSECA GAB. 2004. Hotspots. Biodiversidad amenazada II, México City: CEMEX, 392 p.

MUSCAT E AND MOROTI MT. 2018. Predation of Rhinella ornata (Anura: Bufonidae) by the water snake Erythrolamprus miliaris (Squamata: Dipsadidae) in São Paulo, Brazil. Herpetol Notes 11: 449-450.

MUSCAT E, ROTENBERG EL AND MACHADO IF. 2016. Death-feigning behaviour in an Erythrolamprus miliaris (Linnaeus 1758) water snake in Ubatuba, São Paulo, southeastern Brazil (Dipsadidae). Herpetol Notes 9: 95-97.

MYERS CW AND MCDOWELL SB. 2014. New taxa and cryptic species of Neotropical snakes (Xenodontinae), with commentary on hemipenes as generic and specific characters. Bull Am Mus Nat Hist 385: 1-112.

OLIVEIRA RB, FUNK-PONTES GM, MACIEL AP, GOMES LR AND DI BERNARDO M. 2011. Reproduction of Xenodon dorbignyi on the north coast of Rio Grande do Sul, Brazil. Herpetol J 21: 219-225.

OROFINO RP, PIZZATTO L AND MARQUES OAV. 2010. Reproductive biology and food habits of Pseudoboa nigra (Serpentes: Dipsadidae) from the Brazilian Cerrado. Phyllomedusa 9: 53-62.

PANZERA A AND MANEYRO R. 2013. Reproductive biology of the snake Liophis anomalus (Günther, 1858, Dipsadidae, Xenodontinae). Herpetol J 23: 81-87.

PINTO RR AND FERNANDES R. 2004. Reproductive biology and diet of Liophis poecilogyrus poecilogyrus (Serpentes, Colubridae) from southeastern Brazil. Phyllomedusa 3: 9-14.

PIZZATTO L, JORDÃO RS AND MARQUES OAV. 2008. Overview of reproductive strategies in Xenodontini (Serpentes: Colubridae: Xenodontinae) with new data for Xenodon neuwiedii and Waglerophis merremii. J Herpetol 42: $153-162$

PIZZATTO LAND MARQUES OAV. 2006a. Interpopulational variation in reproductive cycles and activity of the water snake Liophis miliaris (Colubridae) in Brazil. Herpetol J 16: 353-362.
PIZZATTO LAND MARQUES OAV. 2006b. Interpopulational variation in sexual dimorphism, reproductive output, and parasitism of Liophis miliaris (Colubridae) in the Atlantic forest of Brazil. Amphibia-Reptilia 27: 37-46.

PLEGUEZUELOS JMAND FERICHE M. 1999. Reproductive ecology of the horseshoe snake (Coluber hippocrepis) in the Iberian Peninsula. J Herpetol 33: 202-207.

PONTES JA, PONTES RC AND ROCHA CF. 2009. The snake community of Serra do Mendanha, in Rio de Janeiro State, southeastern Brazil: composition, abundance, richness and diversity in areas with different conservation degrees. Braz J Biol 69: 795-804.

PRIETO YA, GIRAUDO AR AND LÓPEZ MS. 2012. Diet and sexual dimorphism of Liophis poecilogyrus (Serpentes, Dipsadidae) from the wetland regions of northeast Argentina. J Herpet 46: 402-406.

QUINTELA FM, MARQUES WC AND LOEBMANN D. 2017. Reproductive biology of the Green Ground Snake Erythrolamprus poecilogyrus sublineatus (Serpentes: Dipsadidae) in Subtropical Brazil. An Acad Bras Cienc 89(3 suppl.): 2189-2197.

ROJAS CA, BARROS VA AND ALMEIDA-SANTOS SM. 2019. A histological and ultrastructural investigation of the female reproductive system of the water snake (Erythrolamprus miliaris): Oviductal cycle and sperm storage. Acta Zool 10: 69-80.

SHINE R. 1977. Reproduction in Australian elapid snakes I - Testicular cycles and mating seasons. Austr J Zool 25: 647-653.

SHINE R. 1994. Sexual size dimorphism in snakes revisited. Copeia 1994: 326-346.

SIQUEIRA DM, NASCIMENTO LP, MONTINGELLI GG AND SANTOS-COSTA MC. 2013. Geographical variation in the reproduction and sexual dimorphism of the Boddaert's tropical racer, Mastigodryas boddaerti (Serpentes: Colubridae). Zoologia 30: 475-481.

SIVAN J, PANZERA A AND MANEYRO R. 2016. Male reproductive cycle of a Neotropical snake, Lygophis anomalus (Dipsadidae), in a temperate geographic distribution. S Am J Herpetol 11: 114-118.

STENDER-OLIVEIRA F, MARTINS M AND MARQUES OAV. 2016. Food habits and reproductive biology of tailluring snakes of the genus Tropidodryas (Dipsadidae, Xenodontinae) from Brazil. Herpetologica 72: 73-79.

UETZ P, HOSEK J AND HALLERMANN J. 2016. The Reptile Database. Accessible in http://www.reptile-database.org.

VIDAL N, DEWYNTER M AND GOWER DJ. 2010. Dissecting the major American snake radiation: A molecular phylogeny of the Dipsadidae Bonaparte (Serpentes, Caenophidia). C R Biol 333: 48-55.

VRCIBRADIC D, NIEMEYER J AND NASCIMENTO CA. 2012. Liophis miliaris (Watersnake) Diet. Herpetol Rev 43: 147. 
WALLACH V, WILLIAMS KL AND BOUNDY J. 2014. Snakes of the World: A Catalogue of Living and Extinct Species, Boca Raton: CRC Press, 1227 p.

ZAHER H, GRAZZIOTIN FG, CADLE JE, MURPHY GW, MOURA-LEITE JC AND BONATTO SL. 2009. Molecular phylogeny of advanced snakes (Serpentes, Caenophidia) with an emphasis on South American Xenodontines: A revised classification and descriptions of new taxa. Pap Avul Zool (São Paulo) 49: 115-153.

ZAR J. 1999. Biostatistical analysis. Englewood Cliffs: Prentice-Hall, $663 \mathrm{p}$.

\section{APPENDIX}

Specimens examined:

Brazil: Rio de Janeiro: Angra dos Reis, Ilha Grande (MNRJ 7672); Araruama, Iguabinha (ZUFRJ 444); Barra do Piraí (MNRJ 23613); Cabo Frio (MNRJ 23087); Cachoeiras de Macacu (MNRJ 14023, 18100, 20721-22, 21057-58, 23296, 23367, 24389, 26000, 26246-48, 26250, 26588, CH-UERJ 256); Cambuci (MNRJ 14881); Campos (MNRJ 847-48, 7152, 7695); Casimiro de Abreu (MNRJ 16911-12, 16625, CH-UERJ 530); Comendador Levi Gasparian (MNRJ 15877); Duque de Caxias, Figueira (MNRJ 18466), Jardim Primavera (MNRJ 20539, 24717), Parque do Comércio (MNRJ 24756), Parque Natural Municipal da Taquara (MNRJ 15444, 15794, 15797, 16362, 1641921), São Bento (MNRJ 24765, 25402), Taquara (MNRJ 17004), Xerém (MNRJ 16533, 19831), no specific locality (MNRJ 856); Guapimirim (MNRJ 7038, 7666, 14241, 14243, 14262-63, CH-UERJ 403); Iguaba Grande (MNRJ 18485, 18523); Itaboraí (CH-UERJ 021, 025, 035, 683, 700, ZUFRJ 553); Itaguaí (MNRJ 21504-05); Lage do Muriaé (MNRJ 16409); Macaé (MNRJ 20662, 23521); Magé (MNRJ 7020, 16915-16, 16987, 17925, 19135, 19137, 19168-69, 20439-44, ZUFRJ 831); Mangaratiba, Ilha de Marambaia (RU 012, 016, 021, 375, 1072, 1362-63, 2006, 2028, 2075-76, 2261); Maricá (MNRJ 3994, 19022, 20139, CH-UERJ 607); Mendes (MNRJ 20362,
21857); Miguel Pereira (MNRJ 20673); Niterói, Itaipu (IVB 3037, MNRJ 12581, 17849, 18401, 18519), Pendotiba (IVB 1545, MNRJ 7070), Piratininga (IVB 2506, CH-UERJ 598), Santa Rosa (IVB 404); Nova Friburgo (MNRJ 7021); Nova Iguaçu, Cabuçu (MNRJ 21663), Santa Rita (CH-UERJ 647), Tinguá (MNRJ 9750, 14010, 14307); Paty do Alferes (MNRJ 7019); Petrópolis: MNRJ 1307, 7103, CH-UERJ 642); Piraí (MNRJ 24679); Resende, Serrinha do Alambari (MNRJ 15265-66, 18508), Visconde de Mauá (ZUFRJ 1642); Rio Claro, Lídice (MNRJ 20632); Rio das Flores (MNRJ 15106, 15803); Rio das Ostras (MNRJ 19238, ZUFRJ 248); Rio de Janeiro, Alto da Boa Vista (MNRJ 14632, 25526), Bangu (MNRJ 15209), Barra da Tijuca (MNRJ 23572), Bonsucesso (ZUFRJ 531), Campo Grande (CHUERJ 603, ZUFRJ 1699), Grajaú (MNRJ 15757), Ilha do Fundão (MNRJ 20363, 24755, ZUFRJ 647, 1287), Ilha do Governador (MNRJ 14819), Irajá (MNRJ 22761), Jacarepaguá (MNRJ 851, 1898), Jardim Botânico (MNRJ 25156-58, 25391, 26249), Lagoa (MNRJ 15062), Parque Estadual da Pedra Branca (MNRJ 9224), Parque Natural Municipal da Serra do Mendanha (MNRJ 10953, 10955 56, 10975), Pedra de Guaratiba (MNRJ 17931), Santa Cruz (MNRJ 24263), São Conrado (ZUFRJ 01, 78), Sepetiba (MNRJ 24406), Tanque (MNRJ 22618), Usina (ZUFRJ 1308), Vargem Grande (MNRJ 24986-87), Vargem Pequena (MNRJ 24988), no specific locality (CH-UERJ 425, ZUFRJ 1535); Santa Maria Madalena (MNRJ 16534); São Francisco do Itabapoana (MNRJ 17033); São Gonçalo (IVB 1705, MNRJ 7678); São João da Barra (MNRJ 4499-500, 4614, 7727, 14065-66, 17412, CH-UERJ 325); São João de Meriti (MNRJ 7043-44, 7046, 7101); Saquarema (MNRJ 4908, 7041, 7153, 7652, 21712, 24344); Tanguá: MNRJ 8150 (Ipitangas). Teresópolis (MNRJ 20094, CHUERJ 466, ZUFRJ 499); Vassouras (MNRJ 7665, 24649, CH-UERJ 192); no specific locality (MNRJ 15568, ZUFRJ 1633). 